\title{
Correction to: Genetic analysis of Wnt/PCP genes in neural tube defects
}

\author{
Zhongzhong Chen ${ }^{1,2+}{ }^{(0)}$, Yunping Lei ${ }^{4 \dagger}$, Xuanye Cao ${ }^{4}$, Yufang Zheng ${ }^{1,2,3}$, Fang Wang ${ }^{6}$, Yihua Bao ${ }^{6}$, Rui Peng ${ }^{1}$, \\ Richard H. Finnell ${ }^{1,2,45^{*}}$, Ting Zhang ${ }^{6^{*}}$ and Hongyan Wang ${ }^{1,2,3^{*}}$
}

\section{Correction to: BMC Med Genomics (2018) 11, 38} https://doi.org/10.1186/s12920-018-0355-9

Following publication of the original article [1], it was reported that the article published without the proper disclosure.

Dr. Finnell formerly held a leadership position with the now dissolved TeratOmic Consulting LLC. He also receives travel funds to attend editorial board meetings of the Journal of Reproductive and Developmental Medicine published out of the Red Hospital of Fudan University.

\section{Reference}

1. Chen Z, Lei Y, Cao X, et al. Genetic analysis of Wnt/PCP genes in neural tube defects. BMC Med Genomics. 2018;11:38. https://doi.org/10.1186/ s12920-018-0355-9.

\section{Publisher's Note}

Springer Nature remains neutral with regard to jurisdictional claims in published maps and institutional affiliations.

\begin{abstract}
Author details
${ }^{1}$ Obstetrics and Gynecology Hospital, State Key Laboratory of Genetic, Engineering at School of Life Sciences, Institute of Reproduction and Development, Fudan University, Shanghai 200011, China. ${ }^{2}$ Key Laboratory of Reproduction Regulation of NPFPC, Collaborative Innovation Center of Genetics and Development, Fudan University, Shanghai 200032, China. ${ }^{3}$ Children's Hospital and Institutes of Biomedical Sciences of Fudan University, Shanghai, China. ${ }^{4}$ Departments of Molecular and Cellular Biology and Medicine, Baylor College of Medicine, Houston, TX 77030, USA. ${ }^{5}$ Department of Pediatrics, Dell Pediatric Research Institute, University of Texas at Austin Dell Medical School, Austin, TX 78723, USA. ${ }^{6}$ Beijing Municipal Key Laboratory of Child Development and Nutriomics, Capital Institute of Pediatrics, Beijing 100020, China.
\end{abstract}

Published online: 27 January 2021

The original article can be found online at https://doi.org/10.1186/s1292 0-018-0355-9.

*Correspondence: finnell@bcm.edu; zhangtingcv@126.com; wanghy@fudan. edu.cn

${ }^{\dagger}$ Zhongzhong Chen, Yunping Lei are equal contributors

1 Obstetrics and Gynecology Hospital, State Key Laboratory of Genetic,

Engineering at School of Life Sciences, Institute of Reproduction

and Development, Fudan University, Shanghai 200011, China

${ }^{6}$ Beijing Municipal Key Laboratory of Child Development and Nutriomics,

Capital Institute of Pediatrics, Beijing 100020, China

Full list of author information is available at the end of the article

(C) The Author(s) 2021. Open Access This article is licensed under a Creative Commons Attribution 4.0 International License, which permits use, sharing, adaptation, distribution and reproduction in any medium or format, as long as you give appropriate credit to the original author(s) and the source, provide a link to the Creative Commons licence, and indicate if changes were made. The images or other third party material in this article are included in the article's Creative Commons licence, unless indicated otherwise in a credit line to the material. If material is not included in the article's Creative Commons licence and your intended use is not permitted by statutory regulation or exceeds the permitted use, you will need to obtain permission directly from the copyright holder. To view a copy of this licence, visit http://creativecommons.org/licenses/by/4.0/. The Creative Commons Public Domain Dedication waiver (http://creativeco mmons.org/publicdomain/zero/1.0/) applies to the data made available in this article, unless otherwise stated in a credit line to the data. 